\title{
PRINSIP KERJA SAMA DAN IMPLIKATUR PADA TUTURAN ALIH KODE DALAM FILM-FILM JERMAN
}

\author{
Adha Ahyana Yulianti \\ Universitas Negeri Surabaya \\ adhayulianti@mhs.unesa.ac.id
}

\begin{abstract}
ABSTRAK
Penelitian ini bertujuan untuk mengkaji realisasi prinsip kerja sama dan mencari makna implikatur yang terdapat pada tuturan alih kode dalam film-film Jerman. Penelitian ini menggunakan teori Grice tentang prinsip kerja sama dan implikatur, serta teori Chaer dan Agustina tentang faktor penyebab alih kode. Penelitian ini merupakan penelitian kualitatif. Metode yang digunakan dalam penelitian ini adalah analisis deskriptif. Sumber data dalam penelitian ini adalah tujuh film Jerman yang mengandung tuturan alih kode. Data penelitian ini adalah transkrip tuturan yang mengandung alih kode.Teknik pengumpulan data menggunakan teknik simak dan catat. Hasil penelitian ini menunjukkan bahwa realisasi prinsip kerja sama pada tuturan alih kode dalam film-film Jerman terbagi menjadi dua jenis, yaitu penaatan dan pelanggaran maksim-maksim percakapan. Pada penaatan dan pelanggaran prinsip kerja sama terdapat empat maksim yang ditaati, yaitu maksim kuantitas, kualitas, relevansi, dan cara.Implikatur yang terdapat dalam penelitian ini dibedakan berdasarkan jenisnya, yaitu implikatur percakapan umum dan implikatur percakapan khusus. Pada implikatur percakapan umum terdapat 4 faktor yang mempengaruhi makna implikatur, yaitu faktor penutur, lawan tutur, situasi formal/informal, dan perubahan topik pembicaraan. Pada implikatur percakapan khusus terdapat 5 faktor yang mempengaruhi makna implikatur, yaitu faktor penutur, lawan tutur, kehadiran orang ketiga, situasi formal/informal, dan perubahan topik pembicaraan.
\end{abstract}

Kata Kunci: implikatur, prinsip kerja sama, tuturan alih kode

\section{ABSTRACT}

This research aims at studying the realization of cooperative principle and finding out the meanings of implicature found in the code switching's utterances in the German Films. This research uses the Grice's theory of cooperative principle and implicature and also Chaer and Agustina's theory of code switching's reasons. The research design of this study is a descriptive qualitative. The source of the data for this research are seven German films, which contain code switching's utterances. The data are the transcription of the code switching's utterances and collected by using the documentation and recording technique. The results show that there are 2 kinds of cooperative principles realization: the observance and non-observance conversational maxim. There are four maxims found in the cooperative principle: maxims of quantity, quality, relevance, and manner. There are also five factors affected the meanings of implicature; speaker, hearer, presence of a third person, formal or informal situation, and change of conversation's subject. This research also shows that the implicature found on data are classified based on its types: generalized and particularized conversational implicature. There are four factors that affect the meanings of generalized implicature; speaker, listener, formal or informal situation, and change of conversation's subject. The meanings of particularized implicature are affected by five factors; speaker, listener, presence of third person, formal or informal situation, and change of conversation's subject.

Keywords: code switching's utterances, cooperative principle, implicature 
Jurnal Belajar Bahasa, ISSN 2502-5864, E-ISSN 2503-0329

Volume 3, No. 2, September 2018

\section{PENDAHULUAN}

Pada era globalisasi seperti sekarang ini, fenomena bilingualisme merupakan peristiwa kebahasaan yang terjadi secara merata di seluruh wilayah di dunia. Menurut Bloomfield bilingualism merupakan kemampuan dalam dua bahasa yang sama baiknya seperti penutur asli (native-like control) (Bloomfield, 1973).

Penguasaan dua bahasa yang sama baiknya ini disebut isitlah balanced bilingualism (Spolsky, 1998). Namun demikian, definisi ini dirasa sangat berat sehingga muncul berbagai pendapat lain tentang definisi bilingualism tersebut. Spolsky mengatakan bahwa seorang bilingual adalah seseorang yang memiliki kemampuan fungsional dalam bahasa kedua (functional bilingualism) (Spolsky, 1998).

Hal itu berarti orang yang bilingual adalah orang mampu menggunakan bahasa selain bahasa pertamanya, baik dalam hal membaca, menulis, atau berbicara. Lado berpendapat bahwa bilingualism adalah kemampuan menggunakan bahasa oleh seseorang dengan sama baiknya atau hampirsama baiknya, yang secara teknis mengacu pada pengetahuan dua buah bahasa bagaimana pun tingkatannya (Chaer, 2010). Sejalan dengan pendapat tersebut, Haugen (Chaer, 2010) menyatakan bahwa seorang bilingual tidak perlu secara aktif menggunakan bahasa tersebut, tetapi cukup kalau bisa memahaminya saja. Berdasarkan definisi-definisi di atas, maka bilingualism tidak selalu berarti kemampuan yang sama baiknya antara bahasa pertama (B1) dan bahasa kedua(B2), melainkan juga mencakup tingkatan kemampuan yang beragam.

Definisi yang dikemukan oleh Haugen tersebut dapat dicontohkan melalui bilingualisme bahasa Jerman dan bahasa Inggris yang terjadi di negara Jerman. Sebagai cerminan budaya setempat, maka bilingualisme masyarakat Jerman juga dapat ditemukan dalam film-film Jerman. Tokoh-tokoh dalam film-film Jerman pun sering melakukan peralihan bahasa dari bahasa Jerman ke bahasa Inggris. Hal tersebut tentu saja dilakukan dengan alasan-alasan tertentu sesuai dengan situasi yang terjadi.

Thomason menyebutkan bahwa secara umum terdapat 5 hal yang dapat menyebabkan terjadinya kontak bahasa (Thomason, 2001), yaitu: (1) adanya dua kelompok yang berpindah ke daerah yang tak berpenghuni kemudian mereka bertemu di sana, (2) perpindahan satu kelompok ke wilayah kelompok lain, (3) adanya praktek pertukaran buruh secara paksa, (4) adanya hubungan budaya yang dekat antar sesama tetangga lama, dan (5) adanya pendidikan atau biasa disebut 'kontak belajar'. Berdasarkan pendapat Thomason tersebut, dapat disimpulkan bahwa kontak bahasa dalam sebuah masyarakat tutur dapat disebabkan oleh berbagai faktor, seperti sosial, geografis, politik, ekonomi, dan pendidikan.

Negara Jerman terletak di Eropa Tengah dan berbatasan langsung dengan banyak negara, seperti Belanda, Perancis, Swiss, Austria, Ceko dan Polandia. Dengan letak geografis yang demikian masyarakat Jerman secara tidak langsung pasti 
Jurnal Belajar Bahasa, ISSN 2502-5864, E-ISSN 2503-0329

Volume 3, No. 2, September 2018

mengadakan kontak bahasa dengan masyarakat tutur lain yang berasal dari negara-negara tetangga tersebut. Kontak bahasa tersebut dapat terjadi melalui perpindahan penduduk dari luar negeri yang masuk ke Jerman. Hal tersebut mengakibatkan peristiwa bilingualisme dan multilingualisme di Jerman.

Seiring dengan maraknya bilingualisme serta multilingualisme yang terjadi di tengah masyarakat Jerman, makin banyak pula film-film yang menggambarkan kondisi masyarakat Jerman yang terbiasa menggunakan bahasa asing selain bahasa Jerman dalam pergaulan sehari-hari mereka. Hal tersebut ternyata tidak dibuat tanpa alasan. Pada dasarnya banyak faktor yang mendorong para seniman film dalam berbuat demikian. Imanjaya menjelaskan bahwa berdasarkan teori film, film adalah arsip sosial yang menangkap semangat zaman (Zeitgeist) masyarakat saat itu (Imanjaya, 2006).

Bilingualisme dan multilingualisme sangat erat kaitannnya dengan fenomena alih kode. Hammers dan Blanc mendefinisikan alih kode sebagai strategi komunikasi bilingual yang mengandung penggunaan dua bahasa dalam suatu ujaran, bahkan satu kalimat (Hammers, 1987). Secara lebih sederhana, Appel mengartikan alih kode sebagai gejala peralihan pemakaian bahasa karena berubahnya situasi (Chaer, 2010). Berdasarkan beberapa definisi di atas, maka dapat disimpulkan bahwa alih kode merupakan peristiwa peralihan dari satu bahasa ke bahasa yang lain yang dilakukan dengan maksud tertentu oleh pelakunya.
Dilihat dari sudut pandang pragmatik, fenomena alih kode yang terdapat dalam film-film Jerman tersebut memiliki makna tersirat yang ingin disampaikan oleh penuturnya. Dalam film-film Jerman yang menjadi sumber data penelitian ini, setiap individu memiliki cara tersendiri dalam menyampaikan pesan atau informasi kepada lawan tuturnya. Namun pada dasarnya penutur dan petutur harus memiliki pemahaman yang sama tentang topic tertentu, sehingga percakapan bias berjalan dan pesan dapat dipahami dengan baik. Untuk memahami pesan yang tersirat dalam sebuah tuturan, maka diperlukan pemahaman tentang prinsip kerja sama dalam sebuah percakapan.

Pada saat berinteraksi dengan orang lain, manusia menggunakan bahasa sebagai media komunikasi. Komunikasi yang wajar melibatkan dua pihak, yaitu penutur dan petutur. Grice mengemukakan bahwa komunikasi yang wajar dapat terjadi apabila antara penutur dan petutur patuh pada prinsip kerja sama komunikasi (Grice, 1975).Prinsip kerja sama ini mengharuskan penutur untuk memberi kontribusi sesuai dengan yang dibutuhkan dalam sebuah percakapan. Selanjutnya, prinsip kerja sama ini dibagi menjadi 4 sub-prinsip yang kemudian disebut dengan maksim, yaitu maksim kuantitas, kualitas, relevansi, dan cara. Dalam prinsip kerja sama terdapat dua bentuk realisasi, yaitu penaatan dan pelanggaran maksim. Kedua bentuk realisasi ini memiliki fungsi masing-masing sesuai dengan konteks yang ada. Hal ini senada dengan pendapat Leech bahwa maksim-maksim prinsip kerja sama (1) 
berlaku secara berbeda dalam konteks penggunaan yang berbeda, (2) berlaku dalam tindakan yang berbeda; tidak ada prinsip yang berlaku secara mutlak, atau tidak berlaku sama sekali, (3) dapat berlawanan satu dengan yang lain, dan (4) dapat dilanggar tanpa meniadakan jenis tindakan yang dikendalikannya. Selanjutnya, penaatan dan pelanggaran keempat maksim ini dapat menimbulkan pesan yang berimplikasi, sehingga muncul implikatur (Leech, 1983).

Implikatur merupakan bagian penting dalam sebuah percakapan, karena menurut Basuki implikatur merupakan fenomena bahasa yang digunakan dalam menyampaikan pesan atau makna dalam komunikasi (Basuki, 2005). Brown dan Yulejuga berpendapat bahwa implikatur merupakan suatu konsep yang menerangkan bahwa apa yang diucapkan berbeda dengan apa yang dimaksudkan (Rani, 2004). Jadi, implikatur juga diartikan sebagai makna lain dibalik makna sebuah tuturan.

Grice membedakan dua jenis implikatur, yakni implikatur konvensional dan implikatur percakapan. Keduanya memiliki persamaan, yaitu menyampakaikan makna tambahan di luar makna semantis dari kata-kata yang dituturkan (Grice, 1975). Perbedaannya adalah bahwa di dalam implikatur konvensional implikatur disampaikan tanpa melihat konteks khusus, sedangkan dalam implikatur percakapan apa yang disiratkan bervariasi menurut konteks tuturan tersebut.

Di samping kedua jenis implikatur yang diungkapkan di atas, Grice (dalam

Levinson (1983, hal. 126) membedakan lagi kedua jenis implikatur percakapan yang telah dibahas di atas, yaitu implikatur percakapan khusus dan implikatur percakapan umum. Dalam implikatur percakapan umum tidak diperlukan latar belakang pengetahuan khusus mengenai konteks tuturan. Implikatur percakapan khusus sangat bergantung kepada konteks latar belakang tuturan. Menurut Yule implikatur percakapan ini terjadi dalam konteks yang sangat khusus, sehingga penutur perlu mengasumsikan informasi yang kita ketahui untuk memahami makna jawaban petutur tersebut (Yule, 1996).

Dalam penelitian ini, teori Grice (Grice, 1975) dan Levinson (1983) yang berhubungan dengan implikatur percakapan digunakan sebagai landasan untuk mendeteksi keberadaan implikatur, terutama dalam tuturan yang mengandung alih kode dalam film-film Jerman. Penelitian tentang prinsip kerja sama dan implikatur yang terdapat pada tuturan yang mengandung alih kode pada film-film Jerman ini perlu dilakukan, dalam rangka memperkaya kajian sosiopragmatik terutama yang menghubungkan antara prinsip kerja sama, implikatur, dan alih kode. Topik ini menjadi ketertarikan tersendiri bagi peneliti, melihat banyaknya film-film Jerman yang beredar menggunakan bahasa Inggris di dalamnya. Melalui penelitian ini, maka diharapkan bahwa realisasi prinsip kerja sama dan makna implikatur pada tuturan yang mengandung alih kode dalam film-film 
Jurnal Belajar Bahasa, ISSN 2502-5864, E-ISSN 2503-0329

Volume 3, No. 2, September 2018

Jerman dapat ditemukan deskripsikan.

\section{METODE}

Penelitian ini merupakan penelitian deskriptif kualitatif dan memakai pendekatan gabungan antara pendekatan pragmatik dan pendekatan sosiolinguistik, sehingga disebut juga dengan pendekatan sosiopragmatik. Kajian ini memakai pendekatan pragmatik untuk mendeskripsikan realisasi prinsip kerja sama dan mendeteksi keberadaan implikatur pada tuturan yang mengandung alih kode. Sedangkan pendekatan sosiolinguistik digunakan untuk menafsirkan makna implikatur tuturan yang mengandung alih kode berdasarkan adaptasi teori penyebab alih kode dan teori komponen tutur.

Sumber data penelitianiniadalah filmfilm cerita (Spielfilme) yang diproduksi di negara Jerman. Sampai penelitian ini ditulis, terdapat9 film yang menjadi sumber data penelitian. Film-film tersebut dipilih dengan pertimbangan, bahwa di dalamnya terdapat banyak peristiwa alih kode, baik dari bahasa Jerman ke bahasa Inggris, atau sebaliknya.

Tabel 1

Daftar Film Sumber Data Penelitian

\begin{tabular}{|r|l|l|l|}
\hline No. & \multicolumn{1}{|c|}{ Judul Film } & $\begin{array}{c}\text { Tahun } \\
\text { Produksi }\end{array}$ & Genre \\
\hline 1. & $\begin{array}{l}\text { Nirgendwo in } \\
\text { Afrika }\end{array}$ & 2001 & $\begin{array}{l}\text { Drama, } \\
\text { Sejarah }\end{array}$ \\
\hline 2. & $\begin{array}{l}\text { The Bourne } \\
\text { Identity }\end{array}$ & 2002 & $\begin{array}{l}\text { Action, } \\
\text { Thriller }\end{array}$ \\
\hline 3. & $\begin{array}{l}\text { Der } \\
\text { BaaderMeinho } \\
\text { fKomplex }\end{array}$ & 2002 & $\begin{array}{l}\text { Drama, } \\
\text { Politik }\end{array}$ \\
\hline 4. & $\begin{array}{l}\text { Inglorious } \\
\text { Bastards }\end{array}$ & 2009 & $\begin{array}{l}\text { Action, } \\
\text { Sejarah }\end{array}$ \\
\hline
\end{tabular}

\begin{tabular}{|r|l|l|l|}
\hline 5. & Friendship! & 2010 & $\begin{array}{l}\text { Drama, } \\
\text { Komedi }\end{array}$ \\
\hline 6. & $\begin{array}{l}\text { Der Ganz } \\
\text { Grosse Traum }\end{array}$ & 2011 & $\begin{array}{l}\text { Drama, } \\
\text { Olahraga }\end{array}$ \\
\hline 7. & Oh Boy & 2012 & $\begin{array}{l}\text { Drama, } \\
\text { Komedi }\end{array}$ \\
\hline 8. & $\begin{array}{l}\text { Girl on A } \\
\text { Bicycle }\end{array}$ & 2013 & $\begin{array}{l}\text { Drama, } \\
\text { Komedi }\end{array}$ \\
\hline 9. & Rush & 2013 & $\begin{array}{l}\text { Drama, } \\
\text { Olahraga }\end{array}$ \\
\hline
\end{tabular}

Penelitian ini bersifat kualitatif, sehingga peneliti berperan sebagai human instrument. Hal ini sesuai dengan pendapat Sugiyono (2009) bahwa instrument utama atau alat penelitian adalah peneliti itu sendiri. Jadi peneliti bertugas untuk mengumpulkan, mengidentifikasi,menganalisis data, dan membuat kesimpulan.

Data dalam penelitian ini dikumpulkan melalui teknik simak dan catat. Menurut Subroto (2007) yang dimaksud dengan metode simak dan catat ialah teknik penyimakan terhadap pemakaian bahasa lisan dan mengadakan pencatatan terhadap data yang relevan dengan sasaran dan tujuan peneliti. Dalam penelitian ini data berupakutipan-kutipan tuturan yang mengandung alih kode dari bahasa Jerman ke bahasa lain dan sebaliknya, baik yang menaati maupun yang melanggar prinsip-prinsip kerja sama.Dalam rangka memudahkan proses analisis pada tahapan selanjutnya, data dalam penelitian ini dikodifikasi berdasarkan inisial judul film, jam, menit, dan detik pada saat suatu tuturan berlangsung. Dengan demikian, data (DGGT,01:07:32) diambil dari film Der 
Jurnal Belajar Bahasa, ISSN 2502-5864, E-ISSN 2503-0329

Volume 3, No. 2, September 2018

Ganz Grosse Traum, jam ke-1, menit ke-7, dan detik ke-32.

Setelah data terkumpul, maka yang dilakukan oleh peneliti selanjutnya adalah menganalisis data. Analisis data merupakan usaha yang dilakukan peneliti untuk mengklasifikasi dan mengelempokkan data. Setelah data terkumpul dan diklasifikasikan, kemudian dilakukan pendeskripsian dan penafsiran.

Pendeskripsian berkaitan dengan fokusfokus dalam penelitian ini, sehingga peneliti menggunakan teori-teori sosiolinguistikdanpragmatik, yaitu teoriteori yang berhubungan dengan prinsip kerjasama, implikatur, dan alih kode.

Teknik analisis data yang digunakan dalam penelitian ini adalah metode heuristik. Menurut Leech teknik analisis ini merupakan teknik yang berisi identifikasi daya pragmatik sebuah tuturan dengan merumuskan hipotesis hipotesis dan kemudian mengujinya berdasarkan data-data yang tersedia. Jika hipotesis tidak teruji, maka dibuatlah hipotesis baru (Leech, 1983). Proses ini terus berulang sampai masalah terpecahkan, yaitu ketika hipotesis teruji kebenarannya sehingga tidak bertentangan dengan bukti yang ada. Oleh karena itu, langkah-langkah yang dilakukan dalam menganalisis data dalam penelitian ini, yaitu sebagai berikut: (1) Mendeskripsikan data tuturan yang mengandung alih kode dalam film-film Jerman berdasarkan bentuk realisasi prinsip kerja sama dengan menggunakan teori Grice (1975) tentang prinsip kerja sama dan maksim-maksim percakapan, (2) Mengelompokkan dan mendeskrip- sikan data tuturan yang mengandung alih kode berdasarkan jenis implikatur dengan menggunakan teori Grice dan Levinson tentang jenis implikaturpercakapan, (3) Menafsirkan makna implikatur tuturan yang mengandung alih kode dengan mengadaptasi teori Chaer tentang faktorfaktor penyebab terjadinya alih kode.

\section{PEMBAHASAN}

\section{A. Realisasi Prinsip Kerja Sama pada}

\section{Tuturan Alih Kode}

Prinsip kerja sama adalah sebuah prinsip yang mengatur peserta tuturan agar percakapan berlangsung efektif dan lancar. Oleh karena itu di dalamnya terdapat maksim-maksim yang mengatur penutur agar berusaha apa yang dikatakannya bersifat informatif, benar, relevan, dan jelas bagi lawan tutur. Halini sejalan dengan Grice yang mengemukakan bahwa komunikasi yang wajar dapat terjadi apabila antara penutur dan petutur patuh pada prinsip kerja sama komunikasi (Grice, 1975, hal. 45-47). Dalam praktek kehidupan sehari-hari, termasuk yang tercermin dalam karya seni berupa film, prinsip kerjasama sering kali ditaati dan dilanggar oleh peserta pertuturan untuk menyampaikan maksudmaksud tertentu.

\section{1) Penaatan Prinsip Kerja Sama pada Tuturan Alih Kode}

Dalam penelitian ini, terdapat penaatan prinsip kerjasama, yaitu terhadap maksim kuantitas, kualitas, relevansi, dan cara. Berikut adalah contoh penaatan maksim kuantitas pada tuturan alih kode dalam film Der Ganz Grosse Traum. 
Data 1:

KO: Ich sehe, dass sie mittlerweile eine Gundtügend des Fussballs verinnerlicht hatten. (menulis kata fairplay di papan tulis) Mister Claasen, please?

Saya lihat, akhir-akhir ini Anda terlalu mendalami dasar dari sepak bola. (menulis kata fairplay di papan tulis) Tuan Claasen, tolong?

$\mathrm{CL}$ :Fair play bezeichnet den respektvollen Umgang mit seinen Gegner und untereinander. Fairplay memiliki arti sikap saling menghormati antara lawan dan sesama.

(DGGT,01:07:32)

Percakapan pada data 1 merupakan penaatan maksim kuantitas. Konrad Koch adalah seorang guru bahasa Inggris yang mengajar murid-muridnya melalui permainan sepak bola. Pada saat muridmuridnya berbuat hal yang tidak semestinya, ia menyuruh salah seorang muridnya yang pandai dalam bahasa Inggris untuk menjelaskan apa arti kata fairplay sesungguhnya. la memanggil Claasen dalam bahasa Inggris, dan Claasen pun paham bahwa ia diminta untuk menerjemahkan kata tersebut kepada teman-teman sekelasnya. Claasen berhasil memberikan kontribusi yang sesuai terhadap harapan Koch, sehingga tuturannya bisa dianggap menaati maksim kuantitas. Selanjutnya adalah contoh penaatan maksim kualitas yang ditemukan dalam film Der Ganz Grosse Traum.
Data 2:

KO :Good sport! Release! (Hartung mendorong Bornstedt sampai terjatuh) Sind Sie verletzt? Permainan yang bagus! (Hartung mendorong Bornstedt sampai terjatuh) Apakah Anda terluka?

BO : No, thank you, I am fine. Tidak, terimakasih. Sayatidakapa-apa.

(DGGT,00:33:00)

Tuturan yang terdapat pada data 2 merupakan penaatan terhadap maksim kualitas. Koch mengawasi murid-muridnya bermain bola. Kemudian tiba-tiba Hartung mendorong Bornstedt dengan sengaja sampai ia terjatuh. Koch bertanya kepada Bornstedt apakah ia baik-baik saja. Jawaban Bornstedt tersebut menaati maksim kualitas, karena ia telah menjawab pertanyaan Koch dengan sebenar-benarnya. Selain itu, dalam penelitian ini juga terdapat penaatan terhadap maksim relevansi yang terlihat dalam film The Bourne Identity.

\section{Data 3:}

RE : Was kann ich für Sie tun? Apa yang bias saya lakukan untuk Anda?

JA : Yes, I'm here about a numbered account.

Saya kesini untuk sebuah nomor rekening.

Dalam percakapan pada data 3, seorang resepsionis bank bertanya kepada Jason apa yang bisaia bantu. Jason memberikan jawaban yang relevan terhadap jawaban tersebut, sehingga resepsionis langsung mengerti keinginan Jason. Oleh karena itu, tuturan Jason 
Jurnal Belajar Bahasa, ISSN 2502-5864, E-ISSN 2503-0329

Volume 3, No. 2, September 2018

tersebut dikatakan telah menaati maksim relevansi. Maksim terakhir yang ditaati pada tuturan alih kode dalam penelitian ini adalah maksim cara. Berikut merupakan contoh penaatan maksim cara dalam film Nirgendwo in Afrika.

Data 4:

Tn.R : Sie sind am Leben, Sie sind hier. Machen Sie was draus. I'm sorry, I can't help. Excuse me. Anda masih hidup, Anda di sini. Berusahalah. Maaf, saya tidak bisa membantu. Permisi.

(NIA,00:56:31)

Dalam tuturan yang tersaji pada data 4, Tuan Ruben tidak mau membantu Jettel mencarikan pekerjaan di ladang untuk suaminya. la menyuruh Jettel untuk bersyukur bahwa ia masih hidup dan berusaha mencari solusi sendiri terhadap masalahnya. Cara Tuan Ruben bertutur kepada Jettel tersebut sangat lugas dan jelas, sehingga Jettel langsung memahami bahwa Tuan Ruben tidak bersedia membantunya, sehingga tuturannya bisa dikatakan menaati maksim cara.

Berdasarkan hasilanalisis maksim kuantitas adalah maksim yang paling sering muncul dan juga ditaati. Hal tersebut disebabkan oleh komunikasi yang efektif dan efisien antar tokoh dalam film-film Jerman yang menjadi sumber data penelitian. Peserta tutur percakapan dalam film-film tersebut berusaha sebisa mungkin untuk memberikan informasi yang tidak kurang maupun berlebihan, sehingga komunikasi berjalan lancar.

\section{2) Pelanggaran Prinsip Kerja Sama pada Tuturan Alih Kode}

Selain penaatan,maka terdapat pula tuturan yang melanggar prinsip kerjasama. Berdasarkan proses analisis maka pelanggaran prinsip kerjasama terjadi juga pada keempatmaksim, yaitu maksim kuantitas, kualitas, relevansi, dan cara. Berikut adalah contoh pelanggaran maksim kuantitas yang ditemukan dalam film Nirgendwo in Afrika.

Data 5:

Ny.R : There you are. Please help yourself, Mrs. Redlich. Mein Mann und ich, we have been '36 for the Olympics in Berlin. Mein erstes Mal in Deutschland. God, we were naive. Silakan ambil sendiri, Ny. Redlich. Saya dan suami saya, kami ke Berlin pada saat Olympiade tahun '36. Kali pertama saya di Jerman. Ya Tuhan, kami benar-benar naiv.

(NIA,00:55:44)

Padapenggalanpercakapanpada data 5, Nyonya Ruben sedangmenjamuJettel di rumahnya. la mempersilakan Jettel mengambil kue yang telah disediakan. Kemudian tanpa ditanya, ia menceritakan pengalamannya di Jerman ketika masih muda. Tuturan tersebut melanggar maksim kuantitas, karena Nyonya Ruben memberikan informasi yang berlebihan kepada lawan tuturnya.Selanjutnya, pelanggaran maksim kualitas juga ditemukan dalam penelitian ini.

Data 6:

Ayah Zooey : Where are you going?

Kamu mau kemana?

Ibu Zooey : What are you doing? Apa yang kamu lakukan? 
Jurnal Belajar Bahasa, ISSN 2502-5864, E-ISSN 2503-0329

Volume 3, No. 2, September 2018

$\mathrm{ZO}$

: Sie fahren mich zur

University.

Mereka mengantarkanku ke univeristas.

(FR,01:03:02)

Pada data 6 di atas, ayah dan ibu Zoey bingung karena anak gadis mereka bersiap ikut pergi dengan kedua tamu laki-laki yang beberapa hari menginap di rumah mereka. Ayah dan ibu Zoey lantas bertanya apa yang dilakukannya dan kemana ia ingin pergi. Zoey pun berbohong bahwa Tom dan Veit ingin mengantarkannya ke universitas, padahal ia ingin ikut berpetualang bersama mereka. Jawaban Zoey kepada orang tuanya tersebut melanggar maksim kualitas, karena tuturan tersebut tidak berdasarkan fakta dan tidak memiliki bukti yang memadai. Selain maksim kualitas, pelanggaran maksim relevansi juga banyak ditemukan dalam penelitian ini. Contohnya sebagai berikut.

Data 7:

OT : Ich kann nicht mehr. Muss man sich eigentlich so viel bewegen, wenn man im "Gaul" steht?

Saya tidak mampu lagi. Apakah yang berdiri di depan "goal" juga harus begitu banyak bergerak?

KO : Goal, Mister Schricker. (tersenyum) "Goal", Tuan Schricker. (tersenyum)

(DGGT,00:31:10)

Penggalan percakapan dalam data 7 terjadi di aula sekolah, ketika Koch, seorang guru bahasa Inggris, sedang berlatih sepak bola bersama muridmuridnya. Otto Schricker, seorang murid yang bertubuh gemuk merasa kelelahan berlari, sehingga ia bertanya pada Koch apakah seorang penjaga gawang juga harus terus berlari selama itu. Koch memahami pertanyaan Otto dan pada dasarnya mengijinkan Otto untuk menjadi penjaga gawang, namun jawaban yang ia berikan tidak relevan dengan pertanyaan Otto.Berikutnya pelanggaran maksim yang terakhir yang ditemukan dalam penelitian ini adalah pelanggaran terhadap maksim cara.

Data 8:

$\mathrm{NI}:$ Marlene, komm. Lass mal den Trottel. No wonder she left him.

Marlene, ayo. Biarkan saja pecundang ini.Tidak heran dia (istrinya)

meninggalkannya.

(RUSH,00:52:20)

Tuturan Niki Lauda kepada istrinya, Marlene, pada data 8 melanggar maksim cara karena Marlene sebagai lawan tutur tidak memahami konteks yang dibicarakan Niki. Tuturan Niki kabur bagi Marlene, karena Marlene tidak memahami siapa yang dimaksud Niki dengan "dia" atau "she" karena pada dasarnya tuturan tersebut sengaja diucapkan oleh Niki agar didengar oleh saingannya, James Hunt yang ditinggalkan oleh istrinya karena sikapnya yang buruk.

Berdasarkan hasil analisis maka keempat maksim dalam prinsip kerja sama ditemukan dalam penelitian ini, baik dalam bentuk penaatan maupun pelanggaran. Selain itu, frekuensi kemunculan tuturan alih kode yang menaati dan melanggar maksim kuantitas paling banyak dibandingkan dengan penaatan atau pelanggaran maksimmaksim prinsip kerja sama yang lain. Hal tersebut disebabkan oleh peran maksim 
kuantitas yang dalam suatu percakapan, termasuk seperti dialog dalam film, sangat penting. Melalui tuturan alih kode yang menaati dan melanggar maksim kuantitas, para tokoh dalam film-film Jerman tersebut ingin menyampaikan implikatur tertentu kepada lawan bicaranya.

Selain temuan tentang tuturan yang menaati dan melanggar maksim prinsip kerja sama, peneliti juga menghadapi beberapa kendala selama proses pengumpulan dan analisis data. Meskipun jumlah sumber data dalam penelitian ini tidak dibatasi, namun peneliti kesulitan menemukan film-film Jerman yang didalamnya mengandung tuturan alih kode Jerman-Inggris dan sebaliknya. Di samping itu, jumlah tuturan alih kode yang ditemukan dalam satu sumber data juga tidak berimbang antara satu dan lainnya, sehingga data yang ditemukan masih kurang beragam.

\section{B. Makna Implikatur Percakapan pada Tuturan Alih Kode}

Penelitian ini pertama-tama membedakan implikatur tuturan alih kode yang terdapat dalam film-film Jerman menjadi 2 jenis, yaitu implikatur percakapan umum dan khusus. Perbedaan antara keduanya terletak pada adanya latar belakang konteks tertentu yang telah dipahami bersama oleh penutur dan lawan tutur pada implikatur percakapan khusus, sedangkan pada implikatur percakapan umum konteks khusus tersebut tidak ada.

Selanjutnya, teori Chaer dan Agustina (Chaer, 2010)tentang faktor penyebab alih kode digunakan sebagai pedoman dasar untuk mencari dan menemukan makna dari tuturan alih kode. Menurut Chaer dan Agustina, terdapat 5 faktor penyebab alih kode, yaitu faktor penutur, lawan tutur, kehadiran orang ketiga, situasi formal/informal, dan perubahan topik pembicaraan. Berdasarkan kelima faktor tersebut, maka makna implikatur dari tuturan yang mengandung alih kode dalam film-film Jerman dapat diselediki secara lebih spesifik dengan mempertimbangkan komponenkomponen tutur Hymes yang ada di dalamnya. Dalam hal ini, beberapa komponen tutur yang diperhatikan untuk menemukan makna implikatur, yaitu (1) latar dan suasana, (2) peserta tutur, (3) tujuan, (4) bentuk/isi ujaran, dan (5) nada tutur.

\section{1) Makna Implikatur Percakapan Umum}

Dalam penelitian ini, terdapat 7 makna implikatur berdasarkan faktor penutur, yaitu menunjukkan identitas bilingual penutur, menunjukkan empati, mengakhiri pembicaraan, menunjukkan rasa hormat, memperjelas maksud tuturan, menegaskan tuturan, mempertahankan jati diri penutur, dan menunjukkan rasa tidak percaya. Dari kedelapan makna implikatur berdasarkan faktor penutur tersebut, maka makna menunjukkan identitas bilingual penutur adalah makna yang paling sering muncul, yaitu sebanyak 6 tuturan.

Berdasarkan faktor yng kedua yaitu faktor lawan tutur terdapat makna menyesuaikan dengan bahasa lawan tutur. Akan tetapi kemunculannya sangat jarang jika dibandingan makna-makna implikatur berdasarkan faktor 
sebelumnya. Selanjutnya, faktor yang berpengaruh terhadap makna implikatur tuturan alih kode adalah situasi formal/informal. Dalam hal ini, makna implikatur dilihat dari latar atau suasana ketika tuturan terjadi, apakah situasinya formal atau tidak (Chaer, 2010). Meskipun jumlah tuturan yang ditemukan pada masing-masing makna hanya 1 tuturan, namun hal itu tidak berarti bahwa implikatur yang ada di dalamnya tidak penting. Ketika situasi berubah menjadi informal, maka penutur melakukan alih kode untuk menceritakan pengalaman pribadi.

Faktor terakhir yang berpengaruh dalam menentukan makna implikatur dari tuturan alih kode adalah perubahan topik pembicaraan. Berdasarkan data penelitian, maka ditemukan makna implikatur tuturan yang mengandung alih kode, yaitu menanyakan keadaan seseorang dan membicarakan hal di luar topik utama. Dari semua makna-makna yang ditemukan dalam penelitian ini, makna menunjukkan identitas bilingual merupakan makna yang paling sering ditemuk. Oleh karena itu, dapat disimpulkan bahwa mayoritas penutur melakukan alih kode dalam rangka menunjukkan kemampuannya sebagai bilingual. Penjabaramn mengenai makna implikatur percakapan umum dari tuturan alih kode yang terdapat dalam film-film Jerman ini dirangkum dalam bagan pada diagram 1.

\section{2) Makna Implikatur Percakapan Khusus}

Selanjutnya pada implikatur percakapan khusus, terdapat 6 makna implikatur yang ditemukan berdasarkan faktor penutur, yaitu menunjukkan identitas bilingual penutur, menunjukkan empati, memperjelas maksud tuturan, menyuruh lawan tutur, mempertahankan jati diri penutur, dan menunjukkan kemarahan/emosi. Sebanding dengan implikatur percakapan berjenis umum, maka makna menunjukkan identitas bilingual berjumlah lebih banyak dari makna yang lainnya, yaitu sebanyak 3 tuturan. Sedangkan berdasarkan lawan tutur terdapat makna mengklarifikasi tuturan, dimana lawan tutur ingin memperjelas tuturan yang disampaikan oleh penutur.

Faktor ketiga yang menyebabkan implikatur adalah kehadiran orang ketiga dalam suatu percakapan antara penutur dan lawan tutur. Berdasarkan faktor ini, ditemukan 3 makna implikatur yaitu mengikutsertakan orang ketiga sebanyak 2 tuturan, tidak mengikutsertakan orang ketiga sebanyak 2 tuturan, dan menyindir orang ketiga sebanyak 1 tuturan. Berdasarkan data dalam penelitian ini, maka terlihat jelas bahwa kehadiran orang ketiga berpengaruh terhadap penggunaan alih kode oleh penutur atau lawan tutur. Dengan melakukan alih kode, penutur atau lawan tutur bisa ingin mengikutsertakan orang ketiga dalam topik pembicaraan atau sebaliknya tidak mengikutsertakan. Selainitu, penutur juga bias bermaksud untuk menyindir orang ketiga tersebut.

Berikutnya faktor keempat yang mempengaruhi makna implikatur adalah situasi formal/informal. Ketika peserta tuturan ingin menunjukkan rasa tertarik, atau menegur orang lain, maka situasinya 
Jurnal Belajar Bahasa, ISSN 2502-5864, E-ISSN 2503-0329

Volume 3, No. 2, September 2018

berubah menjadi informal. Namun pada kesempatan lain, alih kode juga mengimplikasikan bahwa pada saat situasi mulai bergeser ke informal, penutur tetap ingin mempertahankan situasi formal pada saat pertuturan terjadi, sehingga terjadilah alih kode.

Faktor terakhir adalah perubahan topik pembicaraan. Dalam hal ini, penutur ingin mengimplikasikan bahwa ia ingin un membicarakan hal di luar topik utama, individu yang bilingual, baik pada sehingga peristiwa alih kode pun terjadi. kepentingan resmi seperti dalam hal Penjelasan mengenai makna implikatur pekerjaan atau tidak resmi seperti percakapan khusus dari tuturan alih kode hubungan antar keluarga dan teman.

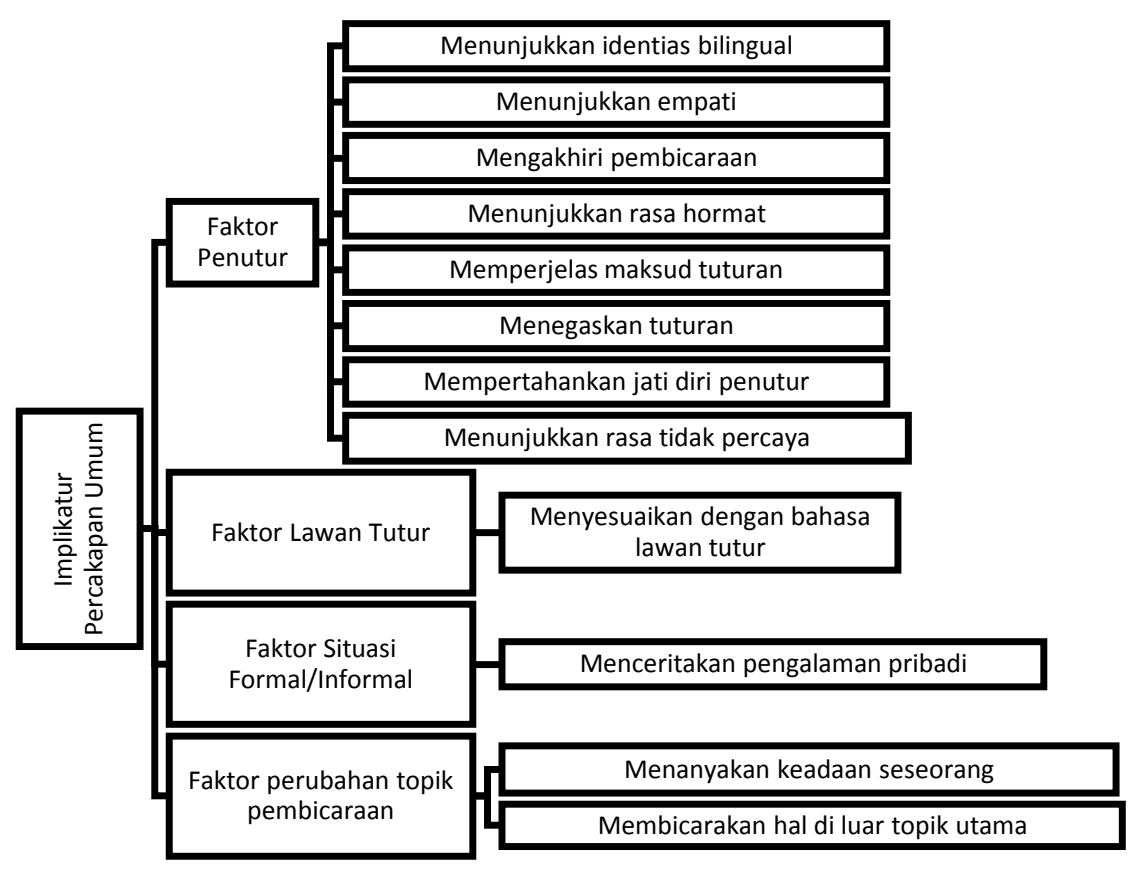

Diagram 1. Makna Implikatur Percakapan Umum 


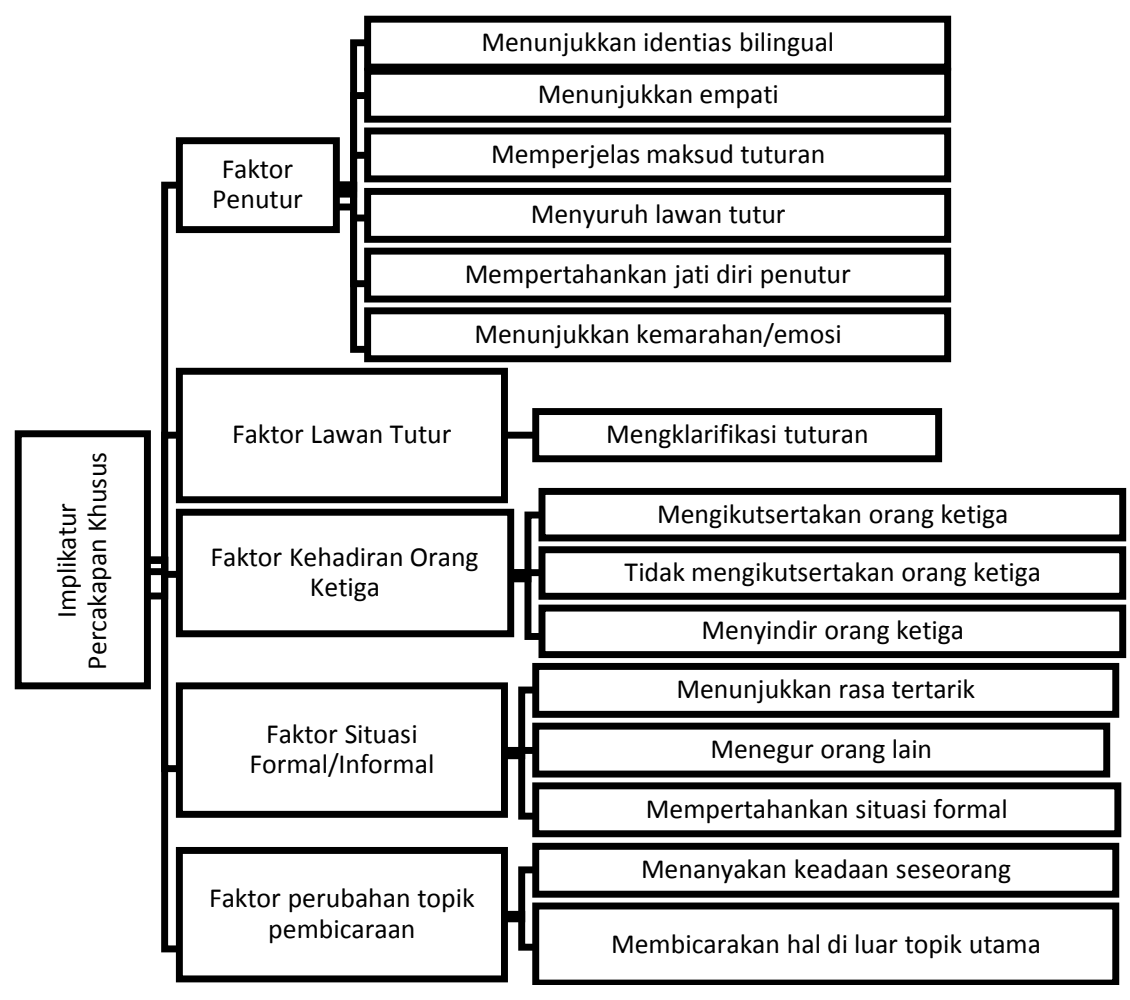

Diagram 2. Makna Implikatur Percakapan Khusus

\section{SIMPULAN}

Berdasarkan hasil dan diskusi penelitian pada bab empat dan lima, maka terdapat beberapa hal yang dapat disimpulkan yaitu sebagai berikut.

1. Pada tuturan alih kode dalam filmfilm Jerman ditemukan dua bentuk realisasi prinsip kerjasama, yaitu penaatan dan pelanggaran prinsip kerjasama. Berdasarkan realisasi prinsip kerjasama pada tuturan alih kode yang terdapat dalam film-film Jerman tersebut, maka pada keempat maksim, yaitu maksim kuantitas, kualitas, relevansi, dan cara terjadi ppenaatan dan pelanggaran. Maksim kuantitas adalah maksim yang paling sering ditemukan kemunculannya, baik ditaati dan dilanggar.Hal tersebut disebabkan oleh peran maksim kuantitas yang dalam suatu percakapan, termasuk seperti dialog dalam film, sangat penting. Melalui tuturan alih kode yang melanggar maksim kuantitas, para tokoh dalam film-film Jerman tersebut ingin menyampaikan implikatur tertentu kepada lawan bicaranya. Dari tuturan alih kode yang menaati maupun melanggar prinsip kerjasama tersebut terdapat implikatur percakapan.

2. Implikatur tuturan alih kode yang ditemukan dalam film-film Jerman dibagi menjadi 2 jenis, yaitu implikatur percakapan umum dan khusus. Berdasarkan hasil analisis, maka terdapat 4 faktor yang mempengaruhi makna dari implikatur umum, yaitu faktor penutur, lawan tutur, situasi formal/informal, dan perubahan topik pembicaraan. Sedangkan pada implikatur 
percakapan khusus ada 5 lima faktor yang mempengaruhi makna implikatur, yaitu faktor penutur, lawan tutur, kehadiran orang ketiga, situasi formal/informal, dan perubahan topik pembicaraan. Dari jenis implikatur umum dan khusus tersebut, makna implikatur menunjukkan identitas bilingual dan menyesuaikan dengan lawan tutur adalah makna yang paling banyak ditemukan dari kedua jenis implikatur tersebut. Hal itu bermakna bahwa mayoritas tujuan utama seseorang, terutama orang Jerman mengganti bahasanya ke bahasa Inggris, atau sebaliknya, adalah untuk menunjukkan kemampuannya sebagai individu yang dapat berkomunikasi dalam bahasa asing (Inggris) kepada lawan tutur, atau untuk menyesuaikan diri dengan bahasa yang lebih dipahami oleh lawan tuturnya, sehingga percakapan antar kedua belah pihak dapat berjalan secara efektif.

Daftar Rujukan

Basuki, I. A. (2005). Linguistika: Teori dan Terapannya. Yogyakarta: Grafika Indah.

Bloomfield, L. (1973). Language. Chicago: Yule, G. (1996). Pragmatik. Yogyakarta : Holt, Rinehart, and Winston Inc.
Chaer, A. d. (2010). Sosiolinguistik Perkenalan Awal. Jakarta: Rineka Cipta.

Grice, H. (1975). Logic and Conversation. University College London.

Hammers, F. d. (1987). Bilinguality and Bilingualism. . Cambridge: Cambridge University Press.

Imanjaya, E. (2006). A to $Z$ About Indonesian Film. Bandung: DAR! Mizan.

Leech, G. (1983). Prinsip-prinsip Pragmatik. (M. D. Oka., Penerj.) Jakarta: Universitas Indonesia Press.

Levinson, S. C. (1983). Pragmatics. Cambridge: Cambridge University Press.

Rani, A. (2004). Analisis Wacana; Sebuah Kajian Bahasa dalam Pemakaian. Malang: Bayumedia Publishings.

Spolsky, B. (1998). Sociolinguistics. Hong Kong: Oxford University Press.

Subroto, E. (2007). Pengantar Metode Penelitian Linguistik Struktural. Surakarta: LPP dan UPT dan UNS Press.

Sugiyono. (2009). Metode Penelitian Bisnis (Pendekatan Kuantitatif, Kualitatif, dan R\&D). Bandung: Alfabeta.

Thomason, S. G. (2001). Language Contact: An Introduction. Edinburg: Edinburg University Press Ltd.

Penerbit Pustaka Pelajar. 